Article

\title{
Metasedimentary Metatexites with Trondhjemitic Leucosomes from NE Sicily: Another Example of Prograde Water-fluxed Melting in Collisional Belts
}

\author{
Patrizia Fiannacca * and Rosolino Cirrincione \\ Dipartimento di Scienze Biologiche, Geologiche e Ambientali, Università di Catania, 95131 Catania, Italy; \\ r.cirrincione@unict.it \\ * Correspondence: pfianna@unict.it
}

Received: 10 February 2020; Accepted: 27 March 2020; Published: 29 March 2020

\begin{abstract}
Trondhjemitic leucosomes, hosted in late Variscan metasedimentary migmatites from the upper amphibolite-facies basement of the north-eastern Peloritani Mountains (southern Italy), have petrographic and geochemical features consistent with their origin as near-pure melts derived from in situ water-fluxed melting of their paragneiss host-rocks. Comparison with results of experimental melting and thermodynamic modelling of metasedimentary rocks suggests a dominant derivation of the leucosomes by melting, at c. $1.0 \mathrm{GPa}$ and $700{ }^{\circ} \mathrm{C}$, metagreywackes with a high pelitic content. Migmatization likely began at the thickening-related baric peak, or during the early post-collisional exhumation stages. A subsequent heating stage following the decompression and solidification of the leucosomes triggered a second melting stage, involving muscovite and biotite incongruent breakdown, with an associated production of peritectic sillimanite and garnet, and small leucogranitic patches within the trondhjemitic leucosomes. These melting events can be framed in the typical clockwise P-T-(t) evolution of the Variscan Belt in western and southern Europe, depicting collision-related thickening followed by widespread migmatization, starting close to the baric peak at c. $345 \mathrm{Ma}$ and continuing during exhumation, with a duration of c. $25 \mathrm{Ma}$, up to c. $320 \mathrm{Ma}$.
\end{abstract}

Keywords: migmatite; trondhjemite; fluid-present melting; petrography; geochemistry; Variscan Belt; Peloritani Mountains; southern Italy

\section{Introduction}

Trondhjemitic leucosomes and small plutons produced by water-fluxed melting of metasedimentary rocks are rather uncommon occurrences in the geological record of the continental crust. They are, however, important markers of crustal evolution, since their occurrence is typically associated with the inception of crustal melting in collisional-related settings. This is both because metasedimentary rocks such as metapelites and metagreywackes are the most fertile crustal rock types, and because the addition of water has the effect of further lowering their solidus, allowing significant amounts of melt to be produced at relatively low temperatures (e.g., $>20 \%$ vol. at $\mathrm{T}<720{ }^{\circ} \mathrm{C}$; [1]).

It has long been proposed (e.g., [2,3]) that leucosomes produced by fluid-enhanced melting represent the earliest appearance of melt during the prograde upper amphibolite-facies metamorphism of thickening orogenic belts. This early melting stage may precede by more than 15 Ma peak metamorphism and the associated production of large volumes of granitic rocks by fluid-absent melting reactions involving muscovite and biotite incongruent breakdown. Since these early S-type melts are produced during the prograde heating path of the orogenic belts, they can persist in a molten state for tens of million years, influencing the rheological properties of the deep-middle crust and possibly playing a role in initiating orogenic relaxation and decompression. As a consequence, 
early melts produced by the water-fluxed melting of paragneisses can provide significant insights not only into the initial stages of the chemical differentiation of the continental crust, but also its thermal and rheological evolution.

Several studies have suggested that granitoid rocks produced by crystallization of these early-formed melts may be identified by their distinctive major- and trace-element features. These include, in addition to high $\mathrm{Na} / \mathrm{K}$ ratios, low $\mathrm{Rb} / \mathrm{Sr}$ ratios, low HFSE abundances, high Ba abundances and positive Eu anomalies (e.g., [2-7]).

However, before trondhjemitic rocks are used to draw any possible conclusions, it is necessary to verify that their typical mineral assemblages and geochemical features genuinely reflect crystallization from an original trondhjemitic magma. In fact, in late- to post-orogenic settings, trondhjemitic compositions can be achieved also by the loss of evolved, $\mathrm{K}_{2} \mathrm{O}$-rich, granitic melt after the accumulation of early-crystallized plagioclase and quartz [8-12], as well as by the subsolidus replacement of magmatic K-feldspar by a secondary plagioclase during infiltration metasomatism of original granites (e.g., [13-17]).

A preliminary study of the petrographic features of late Variscan migmatitic paragneisses from the north-eastern Peloritani Mountains (southern Calabria-Peloritani Orogen; [18] ), host of the c. 314 Ma trondhjemitic Pizzo Bottino pluton [19,20], and of the major and rare earth elements of their trondhjemitic leucosomes, suggested a dominant origin of those leucosomes by water-fluxed melting of the same paragneisses.

This study aimed to investigate in more detail the origin of the above trondhjemitic leucosomes, taking into account a more complete geochemical dataset including the major, trace and rare earth elements of both leucosomes, mesosomes and melanosomes, in a significantly updated geo-petrological background. In fact, subsequent studies have provided a more comprehensive geochronological framework for the timing of anatexis and granitoid magmatism in the southernmost Calabria-Peloritani Orogen (e.g., [20-23]) and evidence for the generation of metasomatic trondhjemites in the same region of the studied leucosomes $[15,19]$. Furthermore, the present study is framed in the context of the recently revitalized debate on the relevance and role of water-fluxed melting in the evolution of the continental crust (e.g., [24-27]), aiming to provide a constructive contribution to this major subject.

\section{Geo-petrological Background}

The Peloritani Mountains, in north-eastern Sicily (Figure 1), make up the south-western termination of the Calabria-Peloritani Orogen (CPO), a poly-orogenic basement complex connecting the southern Apennines and the Maghrebid Chain ([28] and references therein). The basement rocks of the CPO comprise remnants of Variscan and older mountain chains, incorporated into the Alpine-Apennine orogenic system. The Variscan orogeny was responsible for the formation of most of the CPO basement rocks and was marked by voluminous post-collisional granitoid magmatism. The late Variscan magmatism gave rise first to small, weakly peraluminous trondhjemite plutons, emplaced in the southernmost CPO (Aspromonte Massif and Peloritani Mountains) at c. $314 \mathrm{Ma}[15,19,20]$, then to strongly peraluminous leucogranodiorite-leucogranite plutons scattered throughout the CPO, at c. 304-300 Ma [20,29,30] and, finally, to the composite Serre and Sila batholiths in central and northern Calabria, at c. 297-292 Ma ([21,31-34] and references therein). Granitoid magmatism was followed by late- to post-orogenic rhyolitic to andesitic subvolcanic magmatism [35,36], later evolving to the early breakup of Pangea, as documented by the production of sodic-alkaline to tholeiitic Triassic basalts in northern Calabria [37] as well as in central-western Sicily [38,39]. 


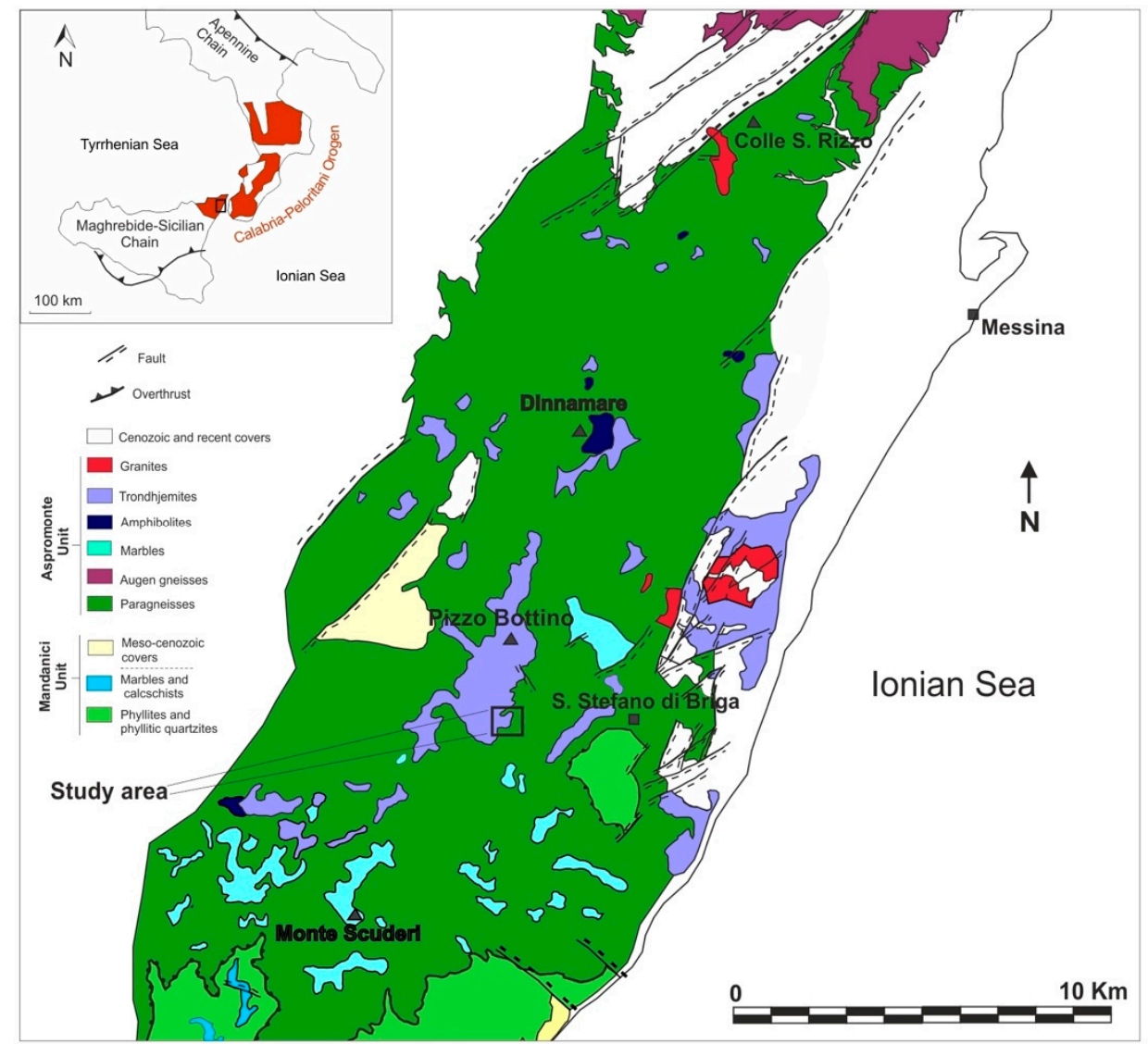

Figure 1. Geological sketch map of the north-eastern Peloritani Mountains (NE Sicily) with location of the studied migmatite outcrop (modified after [19]).

The Peloritani Mountains consist of a set of south-verging basement nappes with metamorphic grade increasing upwards, and remnants of Meso-Cenozoic unmetamorphosed and metamorphosed sedimentary covers [40,41]. The belt is subdivided into two complexes with different tectono-metamorphic histories [42,43]. The Lower Complex, in southern Peloritani, consists of sub-greenschist facies Cambrian to Carboniferous volcano-sedimentary sequences with unmetamorphosed Mesozoic sedimentary sequences [44-46]. The Upper Complex, in the north-eastern sector, consists of two tectonic units, both characterized by clockwise P-T paths: 1) the Mandanici Unit, consisting of greenschist to lower amphibolite facies phyllites and minor phyllitic quartzites, with interbedded layers of metabasites and subordinate marbles and calc-schists [47,48], and 2) the overlying Aspromonte Unit, also cropping out in the adjacent Aspromonte Massif, which consists of amphibolite facies paragneisses, augen gneisses and migmatites, with minor marbles and amphibolites, locally intruded by late Variscan granitoid plutons $[15,18-20,30,49-52]$. Both granitoids and host rocks are locally affected by an Alpine overprint which produced pseudotachylites and cataclastic to mylonitic rocks, as well as retrograde greenschist facies mineralogical assemblages ([53] and references therein).

The late Variscan granitoids of the Aspromonte Unit occur as isolated plutons of a few $\mathrm{km}^{2}$ in size, typically emplaced into upper amphibolite facies rocks. They range from weakly peraluminous trondhjemites, produced by water-fluxed melting of metagreywackes, to strongly peraluminous leucogranodiorites-leucogranites derived from fluid-absent melting of similar, but more pelitic paragneiss sources $[15,19,20,30,54,55]$. P-T estimates for the Variscan metamorphism in the Aspromonte Unit are in the range of $\sim 0.4 \mathrm{GPa}$ at $\sim 550-680^{\circ} \mathrm{C}$, according to [56-58]. Pressure peak values of $0.8 \mathrm{GPa}$ at $\sim 600{ }^{\circ} \mathrm{C}$ and $0.9 \mathrm{GPa}$ at $\sim 530^{\circ} \mathrm{C}$ were obtained through the phase equilibrium modelling of garnet phyllites and schists from the Aspromonte and the underlying Mandanici Unit, respectively [48,59]. 
The dominant metamorphism recorded in the Aspromonte Unit is late Carboniferous-early Permian ( 310-295 Ma; [22,29,60]); upper amphibolite facies metamorphism culminated in partial melting in large areas of the northern Peloritani Mountains, producing widespread metasedimentary metatexites and rarer amphibolite metatexites and metasedimentary diatexites. In particular, electron microprobe dating of monazite from a paragneiss-derived metatexite provided an age of $311 \pm 4 \mathrm{Ma}$ [22], possibly associated with the emplacement of the Pizzo Bottino trondhjemite pluton at $313.7 \pm 3.5 \mathrm{Ma}$ (U-Pb SHRIMP zircon dating; [20]).

The age of $\sim 311 \mathrm{Ma}$, in fact, considerably post-dates the formation age of the trondhjemitic leucosomes, because the $\sim 314$ Ma trondhjemitic pluton sharply cut the local migmatitic foliation, providing evidence for migmatization having occurred significantly earlier than $314 \mathrm{Ma}$. As discussed by Appel et al. (2011) [22], monazite chemical dating did not provide any precise evidence of the timing of early crustal melting and migmatite formation; the obtained 51 apparent ages were inside the range of an unimodal distribution between 290 and $340 \mathrm{Ma}$, which might only tentatively suggest monazite crystallization, at amphibolite-facies conditions (e.g., [61,62]), starting at 340 Ma.

The composition in the metasedimentary migmatites from the Peloritani Mountains is trondhjemitic in about $80 \%-90 \%$ of the leucosomes, with granitic leucosomes tending to be more abundant in the northernmost areas (e.g., $[18,63,64])$.

The migmatites investigated in this study crop out in the Pizzo Bottino (PB) area (Figure 1), where they represent the host rocks of the southern sector of the Pizzo Bottino pluton [15,18-20,22].

\section{Materials and Methods}

Seven metatexite samples were cut in several slabs less than 1-cm-thick, perpendicularly to the foliation, in order to accurately separate leucosomes, mesosomes and melanosomes. Twenty-two separated leucosomes, mesosomes and melanosomes were crushed and analysed for major and trace elements (including rare earth elements) at Actlabs, Ancaster, Canada using the analytical package 4 Lithores (major elements fusion ICP, trace elements' fusion ICP/MS). Relative errors are 5\% or less for major elements (>1 wt. \%) and about 5\%-15\% for most minor and trace elements; analytical procedures and uncertainties are available at http//:actlabs.com. Major and trace element compositions for the analysed samples are given in Supplementary Table S1. Geochemical data were plotted using the GCDkit software [65].

\section{Results}

\subsection{Petrography}

Studied migmatites are metatexites, with the main foliation defined by alternating leucosomes, mesosomes and melanosomes of variable thicknesses (Figure 2). Leucosomes are up to several $\mathrm{cm}$-thick and are typically rimmed by $2-5$-mm-thick melanosomes that, in turn, can have no associated mesosome, or develop different thicknesses on the different mesosomes' sides. Leucosomes usually show an irregular shape and are delimited by indented or diffuse margins. Discordant leucosomes have not been observed in the whole studied area.

Leucosome grain size is mainly coarse, with plagioclase and quartz up to $2 \mathrm{~cm}$ in size, but medium-grained leucosomes also occur. The grain size is typically coarser than that of the associated mesosomes and melanosomes, with a tendency to be larger in the thicker leucosomes. Furthermore, larger leucosomes show a random to weak fabric, with a hypidiomorphic to allotriomorphic magmatic texture. Some thin leucosomes display a more marked anisotropy, with plagioclase and biotite parallel to the mesosome schistosity, but without microstructural features suggestive of deformation at suprasolidus conditions, such as submagmatic fractures or chessboard extinction in quartz. The leucosome-forming minerals are quartz, plagioclase \pm K-feldspar, with lesser amounts of biotite, muscovite, sillimanite and, in a few samples, garnet; accessory phases are scarce apatite, zircon, monazite and opaques. The overall leucosome composition is trondhjemitic, with the scarce K-feldspar 
occurring as scattered interstitial or subhedral phases. However, in some leucosomes, K-feldspar occurs, in much higher amounts, as larger patches, sometimes poikilitic, forming discrete microdomains of leucogranitic composition. Plagioclase from trondhjemitic domains is euhedral to subhedral and usually surrounded by large quartz crystals, with or without interstitial muscovite (Figure 3a,b); accumulations of touching euhedral-subhedral plagioclase are locally present. On the other hand, plagioclase from the leucogranitic domains is subhedral to anhedral, with lobate boundaries towards quartz and K-feldspar, suggesting that these discrete domains are formed by near-eutectic crystallization from a leucogranitic melt (Figure 3c). Especially in the latter domains, plagioclase is sometimes turbid in appearance, due to porosity development and the associated massive crystallization of crypto- to microcrystalline alteration products such as clinozoisite, sericite and oxides; it is also characterized by inclusions of microcline and quartz and/or the development of myrmekites at the contact with microcline (Figure 3d). This plagioclase is interpreted as a secondary phase deriving from the replacement of primary microcline (e.g., [15]), but it is notable that the amount of this secondary phase typically accounts for less than $5 \%$ vol. of the leucosomes, with a negligible impact on the whole leucosome composition.
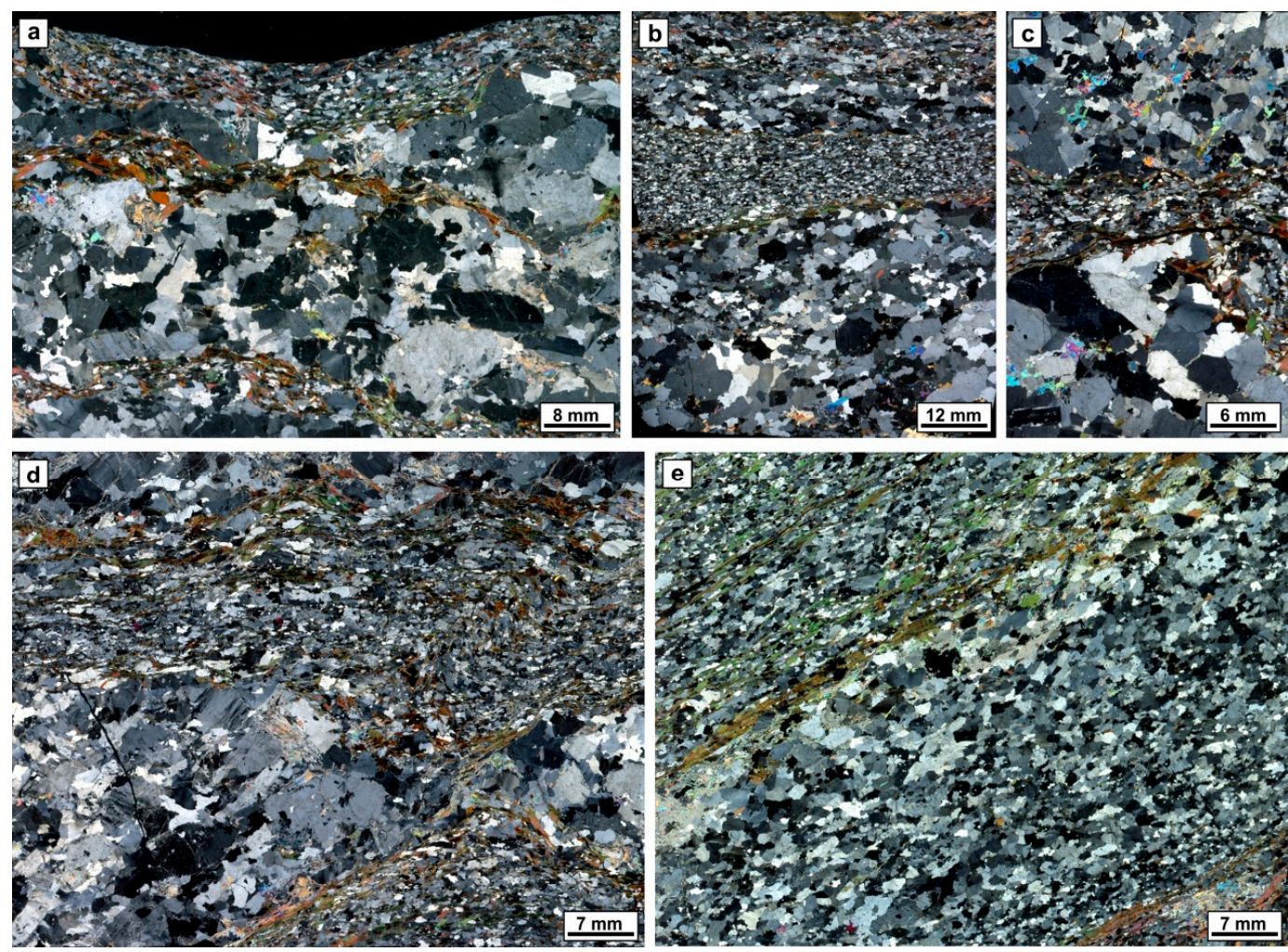

Figure 2. Representative thin-section scans of migmatite samples from Pizzo Bottino (crossed polars). (a) sample PB14a, characterized by a Bt-rich melanosome of restitic appearance in the upper part of the image, with sillimanite at its right termination. Bt-Sill(Ms) rounded nodules occur in the leucosome, in proximity of the melanosome. Leucosome grain size is significantly larger than in the mesosomes; (b) sample PB16, showing a fine-grained mesosome in the centre of the image, bordered on both sides by thin melanosomes of different thickness. The grain size of the thicker leucosome is visibly larger of the thinner leucosome in the upper part of the image; the latter leucosome also shows a more anisotropic fabric; (c) sample PB17, illustrating the distribution of muscovite in the leucosomes, while in the meso-melasonosomes this phase only occurs in rare mm-sized (relic) plats. This sample differs from the others in the absence of K-feldspar and sillimanite; (d) sample PB10, with folded meso-melanosomes. Ms-Sill aggregates occur in the leucosome, especially close to the melanosome, and are typically associated with Kfs-bearing domains (see Figure $3 \mathrm{f}$ for a zoom of the Ms-Sill aggregate from the center of the image); (e) sample PB12a, characterized by an abundance of garnet and granitic domains. 

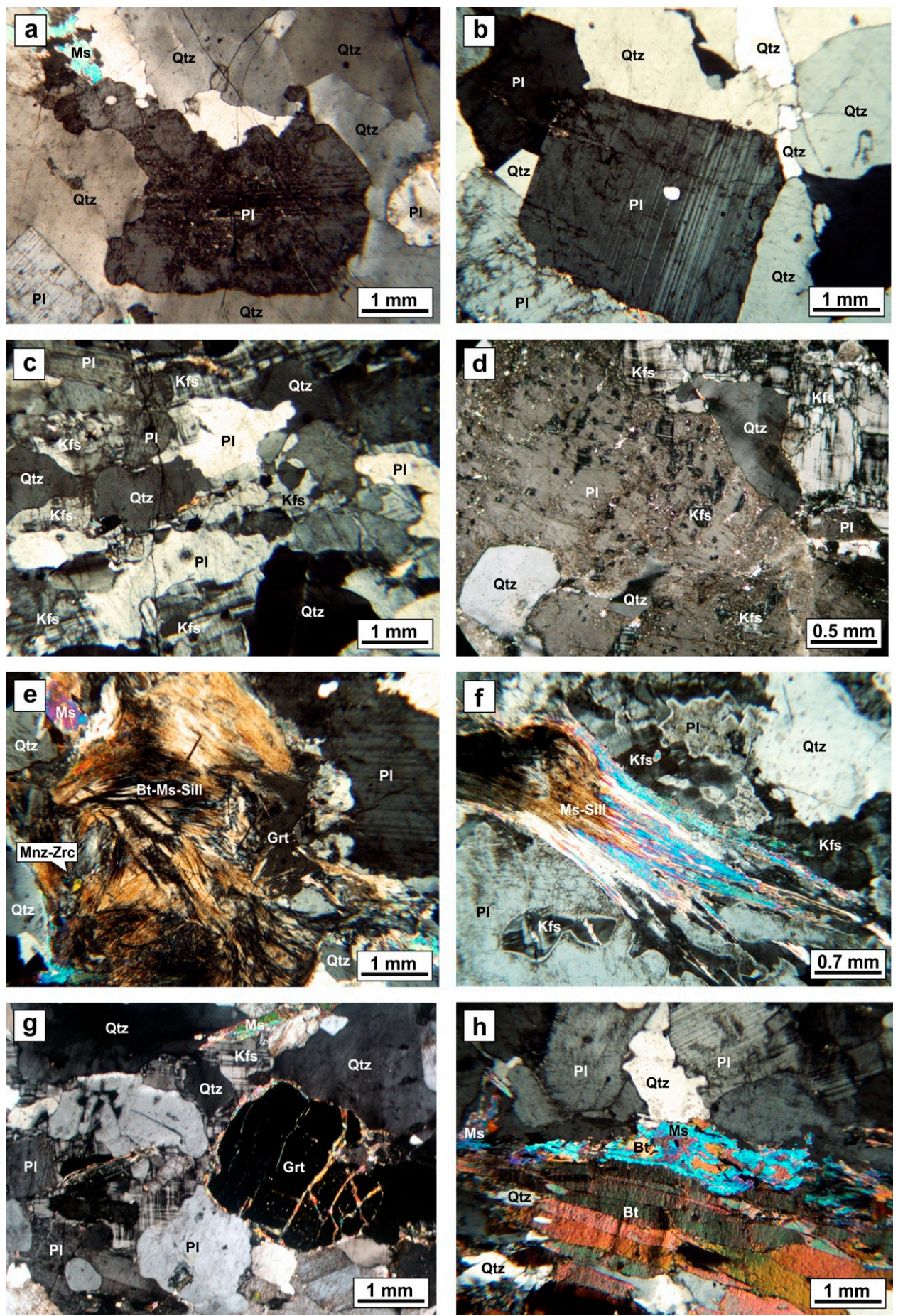

Figure 3. Photomicrographic details of studied migmatites (crossed polars). (a,b) Subhedral plagioclase surrounded by large quartz crystals in leucosome (samples PB17 and PB16, respectively); (c) granitic domain with allotriomorphic texture and tiny garnet in trondhjemitic leucosome (sample PB12a); (d) turbid secondary plagioclase replacing microcline in a granitic domain (sample PB14a); (e) accessory rich, biotite-sillimanite nodular pseudomorph after garnet (sample PB14a); (f) muscovite incongruent melting in a granitic domain (sample PB10); (g) garnet partly replaced by biotite and muscovite in a granitic domain (sample PB12a); (h) biotitic melanosome partly back-reacting to muscovite at the contact with the leucosome (sample PB14a). 
Quartz typically occurs as large crystals, which are sometimes poikilitic and commonly display undulose extinction; shear-related microstructures such as ribbon and sub-grained quartz are locally present.

Biotite is present in low abundance ( $<5 \%$ vol.) as individual euhedral plats which are often associated with, or rimmed by, muscovite and/or fibrolitic sillimanite; it also occurs, in one sample, in rare rounded nodular aggregates representing pseudomorphs after garnet (Figure 2a, Figure 3e). It is usually more abundant in the proximity of the mesosomes and is nearly lacking in the inner portions of large leucosomes; it is therefore likely to mostly represent a phase entrained in the melt. Muscovite occurs as fine plats, alone or associated with biotite, as irregular patches and, finally, as intergrowths with quartz and/or sillimanite. The abundance and size of muscovite is significantly greater in the leucosomes compared to mesosomes and melanosomes. Sillimanite is found as fibrolitic aggregates associated to muscovite \pm quartz \pm biotite, typically in the outer portions of the Kfs-bearing leucosomes, in proximity of the melanosomes.

Garnet, occurring within the granitic domains of two samples, has a euhedral-subhedral shape, and is strongly fractured and inclusion-free. It consists of scattered crystals, less than $1 \mathrm{~mm}$ large; rare, larger crystals, up to $2.5 \mathrm{~mm}$, are typically rimmed by muscovite and biotite, which also seal fractures (Figure 3f). As previously reported, the presence of totally to near-totally replaced garnet is documented in rare biotite-sillimanite pseudomorphic nodules found in one sample.

Mesosomes are heterogeneous in terms of grain size, texture and mineral modal proportions (Figure 2). They consist of different layers made up of: a) quartz-rich fine-grained portions with a schistosity marked by the alignment of biotite as single plats; b) Pl- and Bt-rich medium-coarse-grained portions showing alternating lighter and darker layers and c) composite levels deriving from repetitions of the two former types. The thickness of each mesosome type ranges from less than $1 \mathrm{~cm}$ to slightly more than $5 \mathrm{~cm}$. Mesosome-forming minerals are quartz, plagioclase, biotite, muscovite $\pm \mathrm{K}$-feldspar \pm garnet \pm sillimanite. Accessory phases are apatite, zircon, monazite and opaques.

Biotite is syn-kinematic as single plats or aggregates, or post-kinematic in single plats. Muscovite, fine-grained and occurring in low amounts, is syn-kinematic in single plats or, more frequently, in association with biotite. Low amounts of K-feldspar are present in nearly half of the samples, as single grains of size comparable with the other mineral phases, or as poikiloblastic patches. As in the leucosomes, sillimanite is present in fibrolitic aggregates, associated with muscovite \pm biotite; it can occur in relatively large amounts only in the proximity of the leucosomes, whereas it is typically absent in the inner parts of the mesosomes. Rare garnet occurs as subhedral deformed grains, most of which are fractured; some garnet is partly surrounded by biotite.

Melanosomes consist of millimetric mafic selvedges rimming the leucosomes, typically with sharp boundaries, while transition towards the mesosomes is often gradual. They are dominantly made up of biotite and minor quartz, but melanosomes containing biotite + quartz + muscovite \pm sillimanite \pm plagioclase are also relatively common (Figure 3g). In particular, sillimanite-free melanosomes usually border leucosomes with no or very scarce K-feldspar, whereas K-feldspar richer leucosomes are more commonly associated with sillimanite-rich melanosomes and/or sillimanite-rich nodules, which also occur within the leucosomes.

\subsection{Geochemistry}

The studied leucosomes have trondhjemitic compositions (Figure 4), with $\mathrm{SiO}_{2}=72.41-76.6$ wt.\%, $\mathrm{Al}_{2} \mathrm{O}_{3}=13.8-16.7$ wt. $\%, \mathrm{~K}_{2} \mathrm{O}<1.96$ wt. $\%, \mathrm{Na}_{2} \mathrm{O}=4.02-5.38$ wt. $\%, \mathrm{CaO}=1.44-1.92$ wt. $\%, \mathrm{FeO}_{\mathrm{t}}+\mathrm{MgO}$ $<1.31$ wt.\% [66]. All the samples are strongly peraluminous, with a peraluminousity index (A/CNK, molar ratio $\mathrm{Al}_{2} \mathrm{O}_{3} / \mathrm{CaO}+\mathrm{Na}_{2} \mathrm{O}+\mathrm{K}_{2} \mathrm{O}$ ) in the range 1.16-1.40, and have a low $\mathrm{Rb} / \mathrm{Sr}$ ratio (0.07-0.14); they are also poor in $\mathrm{Cr}, \mathrm{Ni}, \mathrm{Zr}$ and $\mathrm{P}_{2} \mathrm{O}_{5}$. The abundances of the other trace elements vary largely. 

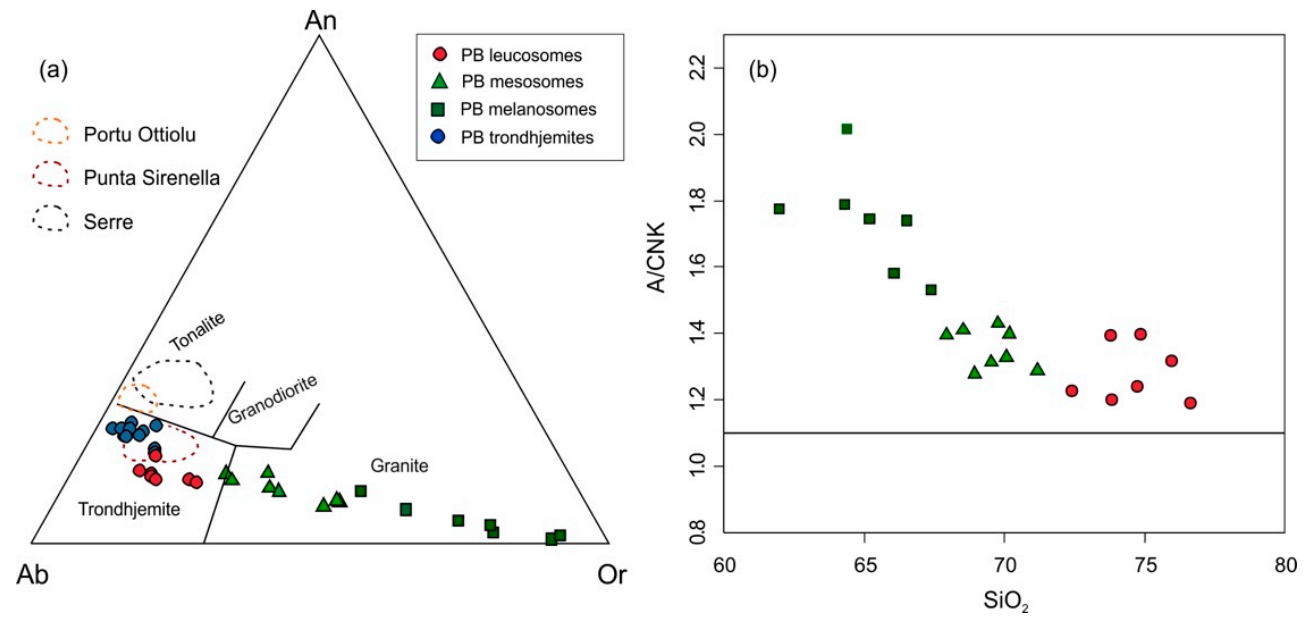

Figure 4. (a) Distribution of the Pizzo Bottino (PB) leucosomes, mesosomes and melanosomes in the feldspar CIPW-normative diagram [66]. Trondhjemites from the Pizzo Bottino Pluton (PB trondhjemites; [19]) are also reported in the diagram, as well as the compositions of trondhjemitic leucosomes from late Variscan metasedimentary migmatites from southern Italy (Serre Massif, Calabria, [67]; Punta Sirenella, Sardinia, [68]; Portu Ottiolu, Sardinia, [69]); (b) Distribution of studied samples in the $\mathrm{A} / \mathrm{CNK}$ vs. $\mathrm{SiO}_{2}$ diagram.

Compared to mesosomes and melanosomes (Figures 5 and 6), leucosomes show, on the whole, higher contents of $\mathrm{SiO}_{2}, \mathrm{Al}_{2} \mathrm{O}_{3}, \mathrm{Na}_{2} \mathrm{O}, \mathrm{CaO}$, $\mathrm{Sr}$ and $\mathrm{Pb}$ and lower contents of $\mathrm{MgO}, \mathrm{FeO}_{\mathrm{t}}, \mathrm{TiO}_{2}, \mathrm{~K}_{2} \mathrm{O}$, $\mathrm{Rb}$, transition elements, Rare Earth Elements (REE) and High Field Strength Elements (HFSE). All the rock types show roughly the same range of $\mathrm{P}_{2} \mathrm{O}_{5}$ and $\mathrm{Ba}$ contents, with the mesosomes exhibiting the largest $\mathrm{Ba}$ variations (with $\mathrm{Ba}$ contents up to $1200 \mathrm{ppm}$ ) and the leucosomes the largest $\mathrm{P}_{2} \mathrm{O}_{5}$ variations.

Correlations with silica are positive for $\mathrm{Al}_{2} \mathrm{O}_{3}, \mathrm{Na}_{2} \mathrm{O}, \mathrm{CaO}, \mathrm{Sr}$ and $\mathrm{Pb}$, unclear for $\mathrm{P}_{2} \mathrm{O}_{5}$ and $\mathrm{Ba}$, and negative for all the other elements. In most cases, trends are nearly collinear and continuous from melanosomes to mesosomes. They show continuity, also including the leucosomes, in the $\mathrm{K}_{2} \mathrm{O}$, $\mathrm{Na}_{2} \mathrm{O}, \mathrm{CaO}, \mathrm{Sr}$ and $\mathrm{Y}$ vs. $\mathrm{SiO}_{2}$ diagrams. On the other hand, large gaps exist between mesosomes and leucosomes in the other diagrams because of the very low contents of Rb, LREE, HFSE and elements hosted by mafic phases in the latter.

Furthermore, despite the general correlations observed, the leucosomes define some internal trends, with well-defined negative correlations for $\mathrm{Al}_{2} \mathrm{O}_{3}, \mathrm{Sr}$ and $\mathrm{Pb}$, less clear negative correlations for $\mathrm{Na}_{2} \mathrm{O}, \mathrm{CaO}, \mathrm{K}_{2} \mathrm{O}$ and $\mathrm{Y}$, and flat trends for the other components. In particular, two samples (PB9L and $\mathrm{PB} 10 \mathrm{~L}$ ) constantly deviate from the general negative trends because of their higher $\mathrm{K}_{2} \mathrm{O}$ and $\mathrm{Ba}$ contents and lower $\mathrm{Na}_{2} \mathrm{O}$ and $\mathrm{Sr}$ contents; they also have relatively higher $\mathrm{Rb}$ and $\mathrm{P}_{2} \mathrm{O}_{5}$ contents and peraluminousity index. Another sample (PB12AL), deviating from the main trends because of its distinctly higher LREE, Y, $\mathrm{Zr}$ and $\mathrm{Nb}$ contents (plus higher Th, U, Hf, Ta and HREE; Table S1), is characterized by relatively higher modal amounts of accessory phases such as monazite, apatite and zircon, as well as of garnet.

In the multi-element diagrams (Figure 7), the leucosomes show a spiked pattern, with peaks for Ba, $\mathrm{U}, \mathrm{K}, \mathrm{Pb}$ and $\mathrm{Eu}$ and troughs for $\mathrm{Rb}, \mathrm{Th}, \mathrm{Nb}, \mathrm{Ce}, \mathrm{Zr}$ and Ti. Apart from sample PB12AL, the leucosomes are visibly depleted in all the elements compared to the mesosomes and melanosomes, except for $\mathrm{Ba}$, $\mathrm{Pb}, \mathrm{Sr}, \mathrm{P}$ and $\mathrm{Eu}$ that have similar or, in the case of $\mathrm{Sr}$, higher abundances.

The chondrite-normalized REE patterns of the leucosomes are characterized by relatively low and variable $\mathrm{REE}(\mathrm{LaN}=20$ to 60 times chondrite) and marked positive Eu anomalies (Figure 7). Patterns are moderately fractionated, with HREE values of 2-10 times chondrite and $\mathrm{La}_{\mathrm{N}} / \mathrm{Yb}_{\mathrm{N}}$ ratios in the range 2.06-16.51. Sample PB12AL is clearly different, due to its high amounts of REE and pronounced negative anomaly of Eu. Apart from the above-mentioned sample, the leucosomes are significantly depleted in all the REE, except Eu, compared to the mesosomes and melanosomes. We note that the 
positive Eu anomaly in the leucosomes is a consequence of the depletion in the other REE compared to the mesosomes and melanosomes, rather than reflecting an increase in Eu in the leucosome; as said, in fact, absolute Eu abundances are similar in all the rock types.
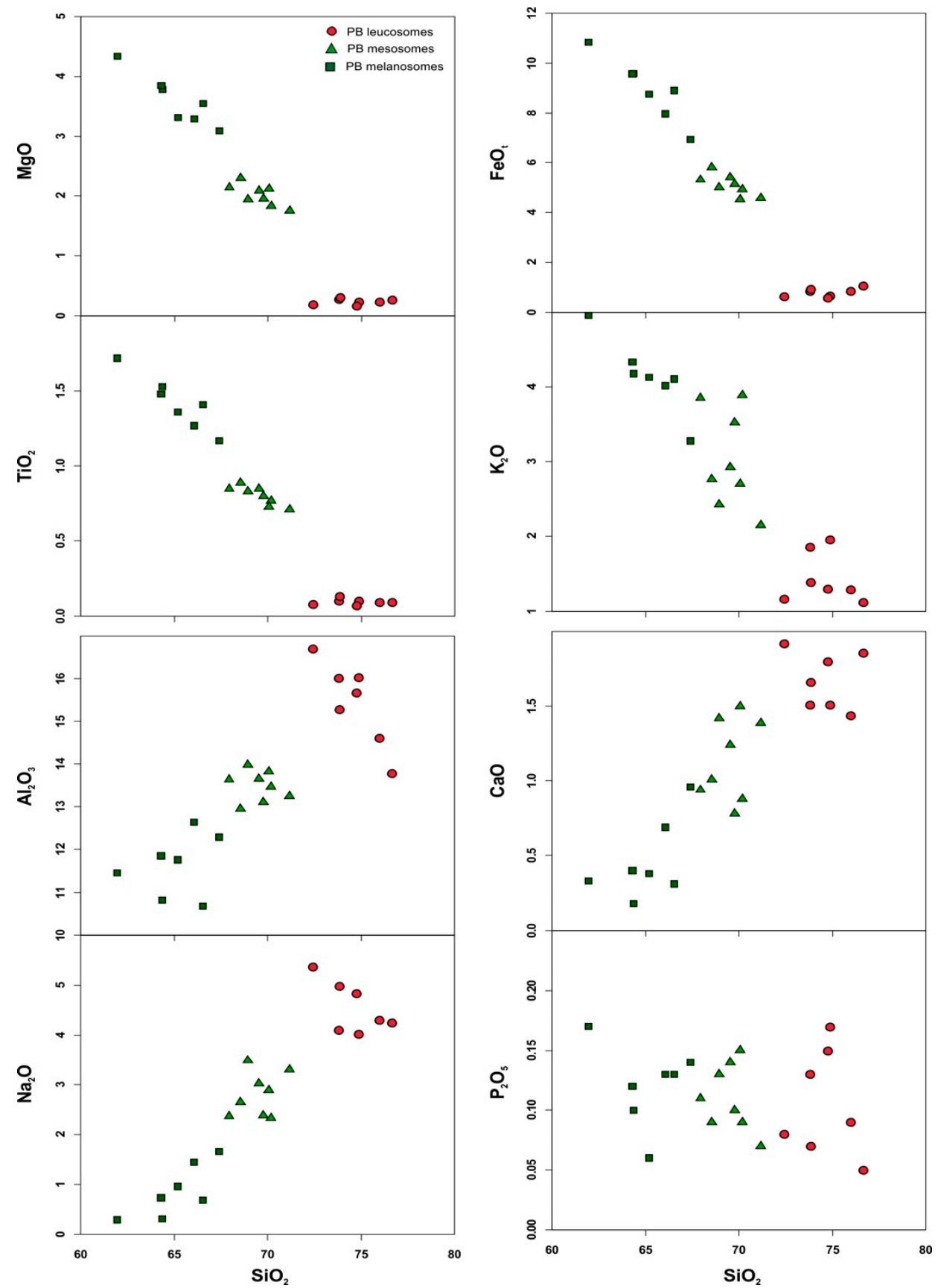

Figure 5. Harker diagrams for major elements (wt. \%). 

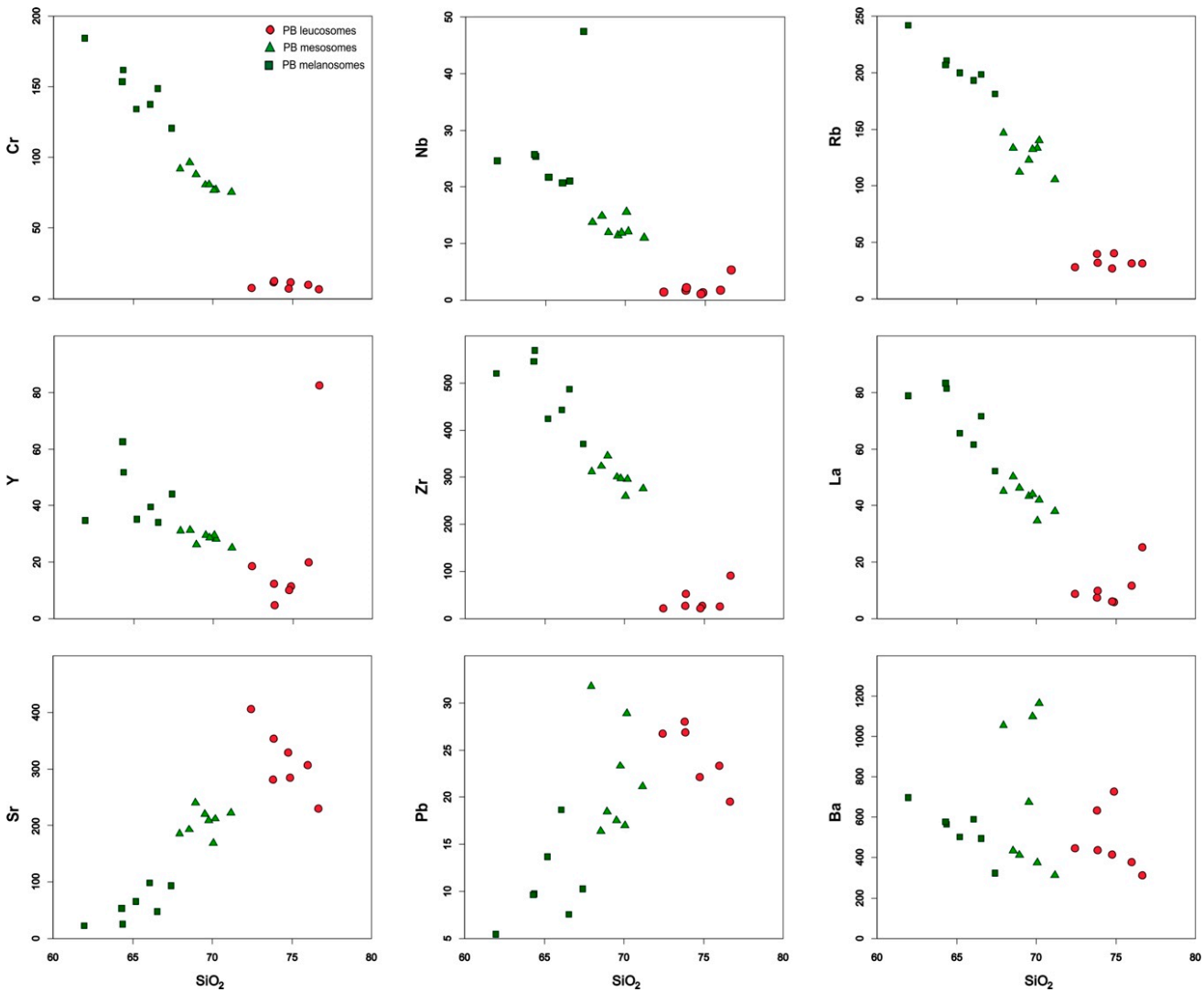

Figure 6. Harker diagrams for selected trace elements (ppm).
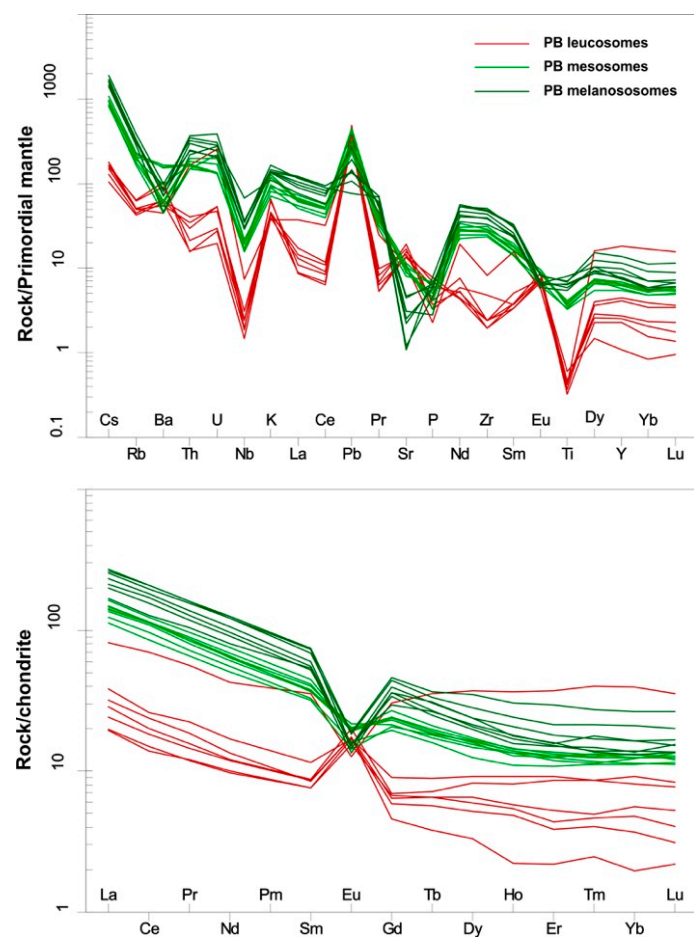

Figure 7. Primitive mantle-normalized trace element patterns and chondrite-normalized rare earth element (REE) patterns for the studied migmatitic rocks. Normalization values are from Sun and McDonough (1989) [70] for primitive mantle and from Boynton (1984) [71] for chondrite. 


\section{Discussion}

\subsection{Field, Petrographic and Geochemical Evidence for Water-fluxed Melting}

Trondhjemitic leucosomes in metasedimentary migmatites are mainly considered to represent cumulates of early crystallizing phases left behind after the segregation of $\mathrm{K}_{2} \mathrm{O}$-rich granitic melts [8-11,72], or products of water-fluxed melting of metapelites and metagreywackes [2,4,19,67-69,73-79].

Cumulates are typified by a framework of euhedral early-formed touching crystals, with the interstices between those crystals filled by the mineral phases crystallizing from the remaining residual melt that was not able to escape (e.g., [80,81]). Therefore, trondhjemites produced by the accumulation of early-formed plagioclase, left behind after the escape of a granitic melt, should be formed by a network of touching euhedral plagioclase. Quartz should be interstitial, filling the small spaces between the plagioclase crystals. This contrasts with the dominant texture in the leucosomes, where plagioclase crystals are significantly spaced and quartz is not interstitial, but instead forms large individual grains. This clearly shows that both plagioclase and quartz grew unimpeded in abundant liquid, reflecting crystallization from a trondhjemitic melt rather than plagioclase accumulation from an original granitic melt.

Local evidence of the crystallization of secondary plagioclase at the expense of original microcline is found in the Kfs-bearing micro-domains of some leucosomes, as documented for metasomatic trondhjemitic rocks in north-eastern Peloritani ([15] and references therein). Nevertheless, the low amounts of this secondary plagioclase in the studied leucosomes only implies limited enhancing of already-trondhjemitic magmatic compositions. Therefore, the petrographic features of the studied leucosomes indicate a dominant origin by crystallization of a trondhjemitic melt.

Furthermore, nearly collinear and continuous trends in the Harker diagrams from melanosomes to mesosomes and leucosomes suggest a dominantly closed-system evolution, which is supported by the irregular shape and indented margin of the leucosomes, which is typical of in situ leucosomes [80].

\subsection{Melting Reactions}

This trondhjemitic melt can be therefore considered to have derived from $\mathrm{H}_{2} \mathrm{O}$-fluxed melting of the host paragneisses according to the reaction: $\mathrm{Ms}+\mathrm{Pl}+\mathrm{Qtz}+\mathrm{H}_{2} \mathrm{O}=$ melt (e.g., [2]). In this melting reaction, muscovite typically dissolves congruently in the melt, without forming the K-feldspar + sillimanite intergrowths typical of fluid-absent melting. In particular, no peritectic K-feldspar is produced by water-fluxed melting reactions, whereas sillimanite has been occasionally reported (e.g., [2-24] and references therein). The dominant occurrence of biotite-rich melanosomes in the studied migmatites is consistent with both fluid-present and fluid-absent partial melting reactions not consuming biotite, and therefore suggestive of relatively low-temperature melting conditions. On the other hand, the minor biotite-sillimanite-rich melanosomes are more likely associated to fluid-absent melting reactions and back reactions, such as the muscovite incongruent melting through the prograde reaction $\mathrm{Ms}+\mathrm{Qtz}=\mathrm{Sil}+$ melt $( \pm \mathrm{Kfs})$ and the restite-melt back-reaction Grt $($ or Crd $)+$ melt $=\mathrm{Bt}+\mathrm{Sill}$ + Qtz (e.g., [82]), respectively.

Evidence of muscovite incongruent melting is found in many leucosomes containing Ms-Sill nodules, which are typically associated to Kfs-rich granitic domains. Furthermore, the occurrence of rare garnet (and Bt-Sill pseudomorphs after garnet) within some of the studied leucosomes suggests local conditions leading to incongruent melting reactions also involving biotite. Despite biotite incongruent melting having been mostly considered to reflect fluid-absent melting at temperatures above c. $780{ }^{\circ} \mathrm{C}$ (e.g., [27] and references therein), recent studies have shown that peritectic garnet produced by incongruent melting of biotite and Fe-rich muscovite can appear at temperatures as low as $700-720^{\circ} \mathrm{C}$, in the presence of free $\mathrm{H}_{2} \mathrm{O}$ (e.g., [1,76,83-86]).

In the studied migmatitic rocks, the occurrence of ferromagnesian peritectic phases is confined to very rare garnet crystals in granitic leucosome microdomains. The stability of biotite during melting is also indicated by its high abundance in the mesosomes and melasonomes, defining a well-preserved 
schistosity, as well as by the lack of evidence of melting affecting this phase, such as the lack of corroded rounded margins. This is also documented by the very low $\mathrm{FeO}$ and $\mathrm{MgO}$ contents in the leucosomes $\left(\mathrm{MgO}+\mathrm{FeO}_{\mathrm{t}}=0.73-1.31 \mathrm{wt}\right.$. \%); furthermore, these mafic contents mostly refer to biotite interpreted as an entrained phase, therefore reflecting more contamination from the host paragneiss rather than biotite dissolution.

In sum, the trondhjemitic composition, combined with the petrographic features of the leucosomes, suggest their derivation from the dominant crystallization of trondhjemite melt, produced by water-fluxed melting involving muscovite congruent dissolution at temperature $\leq 700{ }^{\circ} \mathrm{C}$. This was followed by the crystallization of granitic patches produced by minor muscovite and biotite incongruent melting at higher temperatures, at fluid-absent or fluid-present conditions between the water-saturated solidus and the biotite dehydration melting curve (e.g., [85]).

Textural evidences suggest that these incongruent melting reactions occurred in a separated stage of the migmatite evolution, after solidification of the trondhjemitic leucosomes. This is well illustrated in Figure 3f, showing a Ms-rich nodule interpreted as passively entrained in the first-stage leucosome, reacting to sillimanite and producing a granitic melt; this melt partly consumes the already solidified leucosome plagioclase, which therefore becomes a reactant in this second-stage melting reaction.

\subsection{Comparison with Experimental and Natural Data}

In agreement with all the previous observations, the studied leucosomes show compositions similar to those of experimental melts obtained by $\mathrm{H}_{2} \mathrm{O}$-fluxed melting of metagreywacke-metapelitic schists at pressure of c. 1.0 GPa [2,4], when projected in a normative Ab-An-Or diagram [66] (Figure 4).

The production of trondhjemitic melts by the melting of metasedimentary rocks in the presence of excess water is also supported by the results of thermodynamic modelling of different metasedimentary rocks (e.g., [1,82]), indicating the possible generation of more than $20 \mathrm{wt} \%$ of trondhjemitic melt at temperatures less than $720^{\circ} \mathrm{C}$ from the melting of average metapelites. Furthermore, consistent results also derive from geochemical studies of trondhjemitic nanogranitoids hosted in anatectic paragneisses from several localities (e.g., [87-91]).

The studied leucosomes share a number of chemical features with other trondhjemitic leucosomes from collisional belts, for which a derivation by water-fluxed melting of metasediments has been inferred (e.g., [69] and references therein). These features include high $\mathrm{CaO}$ and low $\mathrm{K}_{2} \mathrm{O}, \mathrm{FeO}$ and $\mathrm{MgO}$ contents, very low $\mathrm{Rb} / \mathrm{Sr}$ ratios, and primitive mantle-normalized multi-element diagrams with positive anomalies of $\mathrm{U}, \mathrm{Sr}$ and $\mathrm{Eu}$, and negative anomalies of $\mathrm{Nb}, \mathrm{Zr}$, Ti and $\mathrm{Rb}$. Slightly fractionated REE patterns, with positive Eu anomalies and $\Sigma$ REE lower than in the adjacent mesosomes and melanosomes, are also typical.

The peloritanian leucosomes from this study are also characterized by the values of specific geochemical parameters that fit in the ranges indicated by Gao et al. (2017) [7], as diagnostic of melts produced by fluid-present melting of metasedimentary rocks (Figures 5-7; Supplementary Table S1). These parameters comprise high Sr (mostly 105-300 ppm), Ba (305-1730 ppm), Sr/Y (3.5-33.5) and $\mathrm{Zr} / \mathrm{Hf}(19.7-44.6)$, and low $\mathrm{Nb}(<11.2 \mathrm{ppm}), \mathrm{Ta}(<2.6 \mathrm{ppm}), \mathrm{Rb}$ and $\mathrm{Rb} / \mathrm{Sr}$ ratios; in particular, the values of the latter parameters in the studied leucosomes are even lower that those proposed by [7] (65-287 ppm and $<2.2$ respectively). This is likely to be related to the marked trondhjemitic character of the studied rocks compared to Himalayan granitoids described by [7]. Another characteristic feature of the fluid-present melting of muscovite in the peloritanian leucosomes is the nearly constant $\mathrm{Rb} / \mathrm{Sr}$ ratio at varying $\mathrm{Ba}$ contents $(\mathrm{Ba}=315-728 \mathrm{ppm}) ; \mathrm{U}$ and Th contents vary in the typical ranges of $0.6-5.4 \mathrm{ppm}$ and 1.1-25.7 ppm, respectively.

An origin of the studied peloritanian leucosomes by in situ crystallization of melts produced by water-fluxed melting of metasedimentary rocks appears, therefore, well supported by both the petrographic and geochemical features of the studied migmatites.

In the Ab-An-Or diagram (Figure 4), the compositions of studied leucosomes from the north-eastern Peloritan are nearly continuous with the compositions of trondhjemites from the nearby late Variscan 
plutons, produced by $\mathrm{H}_{2} \mathrm{O}$-fluxed melting of metagreywackes ([15] and references therein), but visibly shifted toward lower An and higher Or contents.

Comparing with other migmatitic terrains from the same sector of the southern European Variscan Belt, we find that the major element compositions of studied leucosomes are similar to those from migmatitic metagreywackes with various pelitic contents from NE Sardinia $[68,69]$. Trace elements and REE patterns in multi-element patterns are nearly identical (see Figures 6 and 7 in [69]), especially with reference to Punta Sirenella migmatites, with only slightly lower contents in $\mathrm{Nb}-\mathrm{Ti}$, Th-U and REE, and slightly higher Ba contents in the studied leucosomes.

Nevertheless, the peloritanian leucosomes are somewhat depleted in $\mathrm{CaO}$ compared to the Sardinian trondhjemites, particularly considering the leucosomes from Portu Ottiolu [69] and they are also significantly $\mathrm{CaO}$-poorer than the leucosomes from the metasedimentary granulite crust exposed in the Serre Massif (central Calabria; [67]). In this respect, it is also interesting to note the compositions of the Serre leucosomes plot in the tonalite field, irrespective of the metagreywacke or metapelite nature of the host migmatite. The high $\mathrm{CaO}$ abundances of the Serre leucosomes (in the range 2.35-3.37 wt. \%), in combination with high contents of $\mathrm{FeO}$ and $\mathrm{MgO}$ (up to 2.07 and 0.79 wt. \%, respectively) have been considered by [67] to reflect an abundance of restitic plagioclase, biotite and garnet. The entrainment of restitic plagioclase is considered a possible cause of the high $\mathrm{CaO}$ contents in the leucosomes from Portu Ottiolu [69], deviating from the compositions of experimental melts and of melts predicted by thermodynamic models. In this case, however, the authors consider as a more relevant cause the crystal fractionation of K-rich phases such as biotite and muscovite.

Compositions of the studied peloritanian leucosomes are instead very similar to those of experimental melts produced by the melting of muscovite schists at $1.0 \mathrm{GPa}$ and with $2-4 \mathrm{wt}$. \% of added $\mathrm{H}_{2} \mathrm{O}$, corroborating their pure-melt nature, as inferred by previous petrographic and geochemical observations.

The low mafic contents typical of pure melts of the studied leucosomes are efficiently visualized in the modified B-A plot [92] (Figure 8), where the samples plot in the field of the "highly felsic peraluminous granitoids" (fP). These granitoids have compositions representative of pure melts produced at low temperature by low-degree melting $(<20 \%$, for $\mathrm{Fe}+\mathrm{Mg}+\mathrm{Ti}<50)$ of a variety of crustal sources. In fact, as reported by Villaseca et al. (1998) [92], all the melts produced at low melting fractions of crustal rocks such as metapelites, metagreywackes, metadacites and amphibolites plot in the fP field of the diagram, irrespective of the nature of the source rocks. These melt compositions usually have no clear variation trends or, in some cases, vertical trends, but with a tendency of the pelite-derived melts to plot in the upper part of the field. In the B-A diagram [92], the studied leucosomes plot in the upper part of the fP field, together with a few samples of the trondhjemites from the Pizzo Bottino and Forte Cavalli plutons, plotted for comparison [15], while the majority of the plutonic trondhjemites plot along the trend defined by progressive melting of metagreywackes. This is consistent with an origin of the leucosomes by the partial melting of metapelites, or of metagreywackes with a higher proportion of pelitic matrix than the source rocks of the plutonic trondhjemites, which is supported by the trend depicted by the studied mesosomes and melanosomes across the highly peraluminous field of the B-A diagram. Derivation from a pelite-rich source might therefore explain the lower $\mathrm{CaO}$ contents of the studied leucosomes compared with the bulk of the peloritanian plutonic trondhjemites.

There are no available data about the possible source of the fluids that triggered water-fluxed melting in the studied area. The most plausible mechanisms may have involved water released by dehydration reactions occurring at deeper crustal levels, possibly after thrusting of the rock unit containing the studied rocks over phyllosilicate-rich units of lower metamorphic grade. On the other hand, an origin of the fluids by crystallization at a depth of large magmatic intrusions can be confidently excluded; in fact, the earliest occurrences of granitoid magmatism in the $\mathrm{CPO}$ are represented by the c. 314 Ma small trondhjemite plutons, and the bulk of the granitoid magmatism took place later, at c. $300 \mathrm{Ma}$ (e.g., [20,21,29]). 


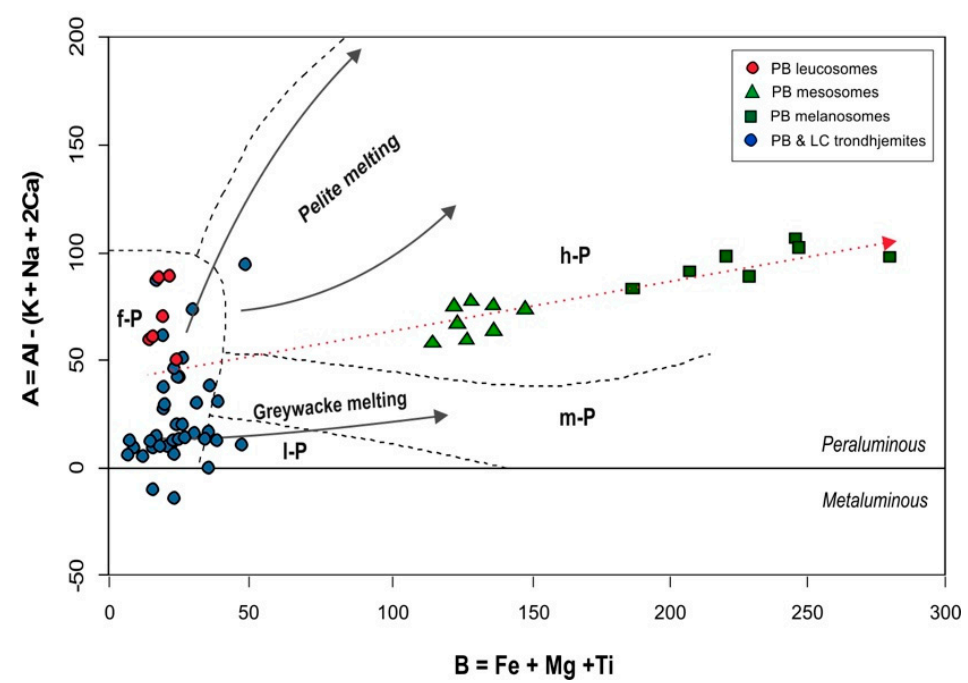

Figure 8. AB diagram ([92]; after [93]) for the studied magmatic rocks. The arrows represent the compositions of progressive melt fractions produced by experimental melting of metapelites and metagreywackes ([92]; and references therein). Compositions of the trondhjemites from Pizzo Bottino (PB; [19]) and the nearby Forte Cavalli granitoid complex (FC; [15]) are also shown in the diagram.

\subsection{Role of $\mathrm{P}, \mathrm{T}, \mathrm{H}_{2} \mathrm{O}$ and Source Composition}

The relative role of $\mathrm{H}_{2} \mathrm{O}$, pressure and source rock composition in controlling the composition of crustal melts has been investigated by [86], through thermodynamic modelling of three turbidite samples with compositions ranging from typical greywacke to pelite. The results from this study suggest that, although the presence of free water tends to produce more sodic melts, the effect of added water on melt composition is minor compared to the effect of high pressure and source rock composition; greywackes, which are Na-richer than pelites, generate more sodic melts than pelites that, instead, typically produce more potassic melts. The melting of pelites in the presence of excess water mostly produces granitic melts at pressure $\leq 0.6 \mathrm{GPa}$, whereas trondhjemitic melts are produced at a higher pressure (e.g., 1.0 GPa; [2]) from the same rocks, or from the water-fluxed melting of greywacke [4].

Pressure has been long known to exert a strong control on the stability of the phases potentially involved in melting reactions (e.g., [2,94]); in particular, increasing pressure increases the stability of muscovite and biotite. At the same time, melting at relatively high pressure, in the presence of excess water, lowers the plagioclase + quartz solidus, therefore producing trondhjemitic melts. The effect of increasing pressure is not limited to the increase in the $\mathrm{Na}_{2} \mathrm{O} / \mathrm{K}_{2} \mathrm{O}$ ratio of the melt; the $\mathrm{CaO}$ content also increases with increasing pressure and $\mathrm{H}_{2} \mathrm{O}$ content, with pressure still playing a major role compared to water ([86] and references therein). An opposite conclusion is proposed by Mayne et al. (2019) [1], who modelled the compositions of melt batches produced by the sequential melting of a metapelite source using a phase diagram approach. Both a water-restricted and water-in-excess system, varying initial magnesium, iron, sodium and calcium contents, P-T conditions and melt extraction threshold, were considered by the authors. Results from Mayne et al. (2019) [1], indicate that the strongest control on melt composition is exerted by the amount of water in the system, followed by the pressure of melting, with a progressively minor influence of the Ca\# of the rock, the Mg\# of the rock and the amount of melt retention in the source before melt extraction.

Considering the results from both the above modelling studies, together with the findings of the experimental works of Conrad et al. (1988) [4] and Patiño Douce and Harris (1998) [2], it appears that both high pressure and water in excess are necessary to produce melts with the high $\mathrm{Na}_{2} \mathrm{O}$ and $\mathrm{CaO}$ contents of the late Variscan trondhjemitic leucosomes from southern Italy ([67-69]; this study). 


\subsection{Implications for Regional Geology}

In particular, migmatites from NE Sardinia have been modelled by P-T pseudosection calculation as being derived by water-fluxed melting of metasedimentary rocks at c. $1.1 \mathrm{GPa}$ and $700{ }^{\circ} \mathrm{C}$, with 1.5-2.0 wt. \% of free $\mathrm{H}_{2} \mathrm{O}[68,69]$. This prograde early melting stage produced trondhjemitic melts, close to thickening-related baric peak. After this stage, migmatites from Punta Sirenella were heated during subsequent decompression, experiencing muscovite incongruent breakdown with an associated production of peritectic kyanite and granite leucosomes. Final melt crystallization occurred at $0.75-0.90 \mathrm{GPa}$ and $660-730^{\circ} \mathrm{C}$, followed by re-equilibration at $650-670{ }^{\circ} \mathrm{C}$ and $0.4-0.6 \mathrm{GPa}$, producing fibrolite-biotite intergrowth and coarse-grained muscovite $[68,95]$. The latter conditions coincide with the P-T conditions of $640-690^{\circ} \mathrm{C}$ and $0.40-0.55 \mathrm{GPa}$ indicated by [69] for complete crystallization of the leucosome melt in the Portu Ottiolu migmatites after a nearly isothermal decompression, leading to the formation of fibrolitic sillimanite.

Similar, near baric peak conditions can be also inferred for the formation of the studied leucosomes from the Peloritani Mountains, where pressures up 0.8-0.9 GPa have been documented in the Aspromonte Unit and in the overlying greenschist facies Mandanici Unit [48,59]. It is notable, however, that kyanite is not present in the mineral assemblages of the studied migmatites, possibly because muscovite incongruent breakdown during the decompression of the peloritanian basement started directly in the stability field of sillimanite. In particular, leucogranitic patches interspersed in the trondhjemitic leucosomes, together with textural evidence for consumption of leucosome plagioclase (e.g., Figure 3), suggest that muscovite incongruent breakdown occurred during a separate event, following leucosome crystallization. This would imply that a stage of isothermal decompression, crossing the pelite-saturated solidus, took place after the early melting stage producing the trondhjemitic melt. This stage was then followed by heating during subsequent decompression, leading to muscovite dehydration melting and the production of peritectic sillimanite and granitic melt.

The timing of crustal melting leading to metatexite formation in the north-eastern Peloritani can also be framed in the same scenario outlined by Cruciani et al. (2019 [96] and references therein). Based on the examination of the geochronological data available for anatectic terrains throughout the European Variscan Belt, a distribution of 76\% of ages at 335-320 Ma, 12\% at 345-335 Ma and 12\% at 320-310 Ma has been highlighted by [96]. According to this analysis, migmatization started at around $345 \mathrm{Ma}$ and climaxed at 335-320 Ma, in a tight time interval of $15 \mathrm{Ma}$, in widely separated regions of the Variscan Belt. In particular, the results of U-Pb zircon and Ar-Ar amphibole dating of amphibole-bearing migmatites from Punta Sirenella, of 324.2 $\pm 4.0 \mathrm{Ma}$ and 317.4 $\pm 2 \mathrm{Ma}$, respectively [96] suggest that partial melting in NE Sardinia persisted from c. $344 \mathrm{Ma}$ to c. 330-320 Ma, by considering the zircon age of $324.2 \pm 4.0 \mathrm{Ma}$ as reflecting the final stage of migmatite formation. On the other hand, the Ar-Ar amphibole age of $317.4 \pm 2$ Ma would represent the re-equilibration of amphibole during cooling after solidification of the leucosome.

Results from the monazite dating of a metatexite sample from Pizzo Bottino [22] revealed a comparable history. In this case, old monazite dates at c. 340 Ma might mark the beginning of melting during the prograde basement path, whereas the main crystallization monazite age of $311 \pm 4 \mathrm{Ma}$ is consistent with a late-stage event experienced by the migmatite after complete solidification of the leucosome. This event is further constrained by SHRIMP zircon dating of $313.7 \pm 3.5$ of the trondhjemites of the Pizzo Bottino Pluton [20] that intrude these migmatites with sharp contacts, cutting the migmatite foliation.

\section{Concluding Remarks}

Evidence from the experimental melting and thermodynamic modelling of metapelites, in conjunction with petrographic and geochemical studies of leucosomes and nanogranitoids from several migmatitic complexes worldwide, all converge to indicate that, where free-water is present, the first melts produced by partial melting of the continental crust during an orogenic cycle are of trondhjemitic composition. 
Trondhjemites are, therefore, important markers of crustal evolution, but their origin as rocks produced by the crystallization of primary trondhjemitic melts, as opposed to rocks with a similar composition produced by plagioclase accumulation or $\mathrm{Ca}-\mathrm{Na}$ metasomatism, first needs to be verified through targeted petrographic and geochemical investigations.

Late Variscan trondhjemitic leucosomes from north-eastern Peloritani Mountains have petrographic and geochemical features consistent with their origin as near-pure melts deriving from the water-fluxed melting of their paragneiss host rocks. Comparison with results of experimental melting and thermodynamic modelling of metasedimentary rocks suggests that the studied leucosomes dominantly derived from the melting at $1.0 \mathrm{GPa}$ and $700{ }^{\circ} \mathrm{C}$ of metagreywackes with a high pelitic content. These melting conditions were likely achieved at the thickening-related baric peak or in the early post-collisional exhumation stages. A subsequent heating stage following the decompression and solidification of the trondhjemitic leucosomes led to minor muscovite and biotite incongruent melting producing peritectic sillimanite, plus rare garnet, and leucogranitic patches within the trondhjemitic leucosomes.

These events can be framed in the typical clockwise P-T-(t) paths inferred for the amphibolite-facies Variscan basement of the Peloritani Mountains, and of most of the other fragments of the Variscan Belt in western and southern Europe. These P-T-(t) paths reflect collision-related thickening followed by widespread migmatization, starting close to the baric peak and continuing during exhumation, in a time interval of c. $25 \mathrm{Ma}$, from c. 345 to c. $320 \mathrm{Ma}$.

The reason why, despite this common P-T-(t) evolution, recorded across the whole Variscan Belt, peraluminous trondhjemitic rocks seem to be a relatively rare occurrence in the geological record of the continental crust, remains to be explored.

Supplementary Materials: The following are available online at http://www.mdpi.com/2076-3263/10/4/123/s1, Table S1: Major and trace element composition of migmatites from north-eastern Peloritani.

Author Contributions: Conceptualization, P.F. and R.C.; Data curation, P.F.; Formal analysis, P.F.; Investigation, P.F.; Methodology, P.F.; Resources, P.F. and R.C.; Writing-original draft, P.F.; Writing-review and editing, P.F. and R.C. All authors have read and agreed to the published version of the manuscript.

Funding: This research received no external funding.

Acknowledgments: We thank two anonymous reviewers for their constructive comments that helped to improve the manuscript. We also thank Antonio Acosta-Vigil for careful editorial guidance and insightful comments and suggestions.

Conflicts of Interest: The authors declare no conflict of interest.

\section{References}

1. Mayne, M.J.; Stevens, G.; Moyen, J.F. A phase equilibrium investigation of selected source controls on the composition of melt batches generated by sequential melting of an average metapelite. In Post-Archean Granitic Rocks: Petrogenetic Processes and Tectonic Environments; Janousek, V., Bonin, B., Collins, W.J., Farina, F., Bowden, P., Eds.; Special Publications; Geological Society: London, UK, 2019; Volume 491. [CrossRef]

2. Patiño Douce, A.E.; Harris, N. Experimental constraints on Himalayan anatexis. J. Petrol. 1998, 39, 89-710. [CrossRef]

3. Prince, C.; Harris, N.; Vance, D. Fluid-enhanced melting during prograde metamorphism. J Geol. Soc. 2001, 158, 233-242. [CrossRef]

4. Conrad, W.K.; Nicholls, I.A.; Wall, V.J. Water saturated and undersaturated melting of metaluminous and peraluminous crustal compositions at $10 \mathrm{~kb}$ : Evidence for the origin of silicic magmas in the Taupo Volcanic Zone, New Zeland, and other occurrences. J. Petrol. 1988, 29, 765-803. [CrossRef]

5. Harris, N.B.W.; Inger, S. Trace element modelling of pelite-derived granites. Contrib. Mineral. Petrol. 1992, 110, 46-56. [CrossRef]

6. Inger, S.; Harris, N. Geochemical constraints on leucogranite magmatism in the Langtang Valley, Nepal Himalaya. J. Petrol. 1993, 34, 345-368. [CrossRef] 
7. Gao, L.E.; Zeng, L.; Asimow, P.D. Contrasting geochemical signatures of fluid-absent versus fluid-fluxed melting of muscovite in metasedimentary sources: The Himalayan leucogranites. Geology 2017, 45, 39-42. [CrossRef]

8. Sawyer, E.W. The role of partial melting and fractional crystallization in determining discordant migmatite leucosome compositions. J. Petrol. 1987, 28, 445-473. [CrossRef]

9. Solar, G.S.; Brown, M. Petrogenesis of migmatites in Maine, USA: Possible source of peraluminous leucogranite in plutons? J. Petrol. 2001, 42, 789-823. [CrossRef]

10. Johnson, T.E.; Hudson, N.F.C.; Droop, G.T.R. Evidence for a genetic granite-migmatite link in the Dalradian of NE Scotland. J. Geol. Soc. 2003, 160, 447-457. [CrossRef]

11. Wang, S.J.; Li, S.G.; Chen, L.J.; He, Y.S.; An, S.C.; Shen, J. Geochronology and geochemistry of leucosomes in the North Dabie Terrane, East China: Implication for post-UHPM crustal melting during exhumation. Contrib. Mineral. Petrol. 2013, 165, 1009-1029. [CrossRef]

12. Nicoli, G.; Stevens, G.; Moyen, J.F.; Vezinet, A.; Mayne, M. Insights into the complexity of crustal differentiation: $\mathrm{K}_{2} \mathrm{O}$-poor leucosomes within metasedimentary migmatites from the Southern Marginal Zone of the Limpopo Belt, South Africa. J. Metam. Geol. 2017, 35, 999-1022. [CrossRef]

13. Drummond, M.S.; Ragland, P.C.; Wesolowski, D. An example of trondhjemite genesis by means of alkali metasomatism: Rockford Granite, Alabama Appalachians. Contrib. Mineral. Petrol. 1986, 93, 98-113. [CrossRef]

14. Essaifi, A.; Capdevila, R.; Lagarde, J.L. Metasomatic trondhjemites and tonalites: Examples in Central Jebilet (Hercynian, Morocco). J. Afric. Earth Sci. 2004, 39, 369-374. [CrossRef]

15. Fiannacca, P.; Basei, M.A.S.; Cirrincione, R.; Pezzino, A.; Russo, D. Water-assisted production of late-orogenic trondhjemites at magmatic and subsolidus conditions. In Post-Archean Granitic Rocks: Petrogenetic Processes and Tectonic Environments; Janousek, V., Bonin, B., Collins, W.J., Farina, F., Bowden, P., Eds.; Special Publications; Geological Society: London, UK, 2019; Volume 491. [CrossRef]

16. Kaur, P.; Chaudhri, N.; Hofmann, A.W.; Raczek, I.; Okrusch, M.; Skora, S.; Baumgartner, L.P. Two-stage, extreme albitization of A-type granites from Rajasthan, NW India. J. Petrol. 2012, 53, 919-948. [CrossRef]

17. Kaur, P.; Chaudhri, N.; Eliyas, N. Origin of trondhjemite and albitite at the expense of A-type granite, Aravalli orogen, India: Evidence from new metasomatic replacement fronts. Geosci. Front. 2019, 10, 1891-1913. [CrossRef]

18. Fiannacca, P.; Cirrincione, R.; Mazzoleni, A.; Pezzino, A.; Sergi, A. Petrographic and geochemical features of Hercynian migmatites from north-eastern Peloritani (northeastern Sicily): Preliminary data. Boll. Accad. Gioenia Sci. Nat. 2005, 38, 151-172.

19. Fiannacca, P.; Brotzu, P.; Cirrincione, R.; Mazzoleni, P.; Pezzino, A. Alkali metasomatism as a process for trondhjemite genesis: Evidence from Aspromonte Unit, northeastern Peloritani, Sicily. Mineral. Petrol. 2005, 84, 19-45. [CrossRef]

20. Fiannacca, P.; Williams, I.S.; Cirrincione, R.; Pezzino, A. Crustal contributions to late Hercynian peraluminous magmatism in the southern Calabria-Peloritani Orogen, southern Italy: Petrogenetic inferences and the Gondwana connection. J. Petrol. 2008, 49, 1497-1514. [CrossRef]

21. Fiannacca, P.; Williams, I.S.; Cirrincione, R. Timescales and mechanisms of batholith construction: Constraints from zircon oxygen isotopes and geochronology of the late Variscan Serre Batholith (Calabria, southern Italy). Lithos 2017, 277, 302-314. [CrossRef]

22. Appel, P.; Cirrincione, R.; Fiannacca, P.; Pezzino, A. Age constraints on Late Paleozoic evolution of continental crust from electron microprobe dating of monazite in the Peloritani Mountains (southern Italy): Another example of resetting of monazite ages in high grade rocks. Int. J. Earth Sci. 2011, 100, 107-123. [CrossRef]

23. Fornelli, A.; Langone, A.; Micheletti, F.; Piccarreta, G. Time and duration of Variscan high temperature metamorphic processes in the south European Variscides: Constraints from U-Pb chronology and trace element chemistry of zircon. Mineral. Petrol. 2011, 103, 101-122. [CrossRef]

24. Weinberg, R.F.; Hasalová, P. Water-fluxed melting of the continental crust: A review. Lithos 2015, 212, 158-188. [CrossRef]

25. Clemens, J.D.; Stevens, G. Comment on 'Water-fluxed melting of the continental crust: A review' by R.F. Weinberg and P. Hasalová. Lithos 2015, 234, 100-101. [CrossRef]

26. Weinberg, R.F.; Hasalová, P. Reply to comment by J.D. Clemens and G. Stevens on 'Water-fluxed melting of the continental crust: A review'. Lithos 2015, 234, 102-103. [CrossRef]

27. Clemens, J.D.; Stevens, G.; Bryan, S.E. Conditions during the formation of granitic magmas by crustal melting-Hot or cold; drenched, damp or dry? Earth Sci. Rev. 2020, 200, 102982. [CrossRef] 
28. Cirrincione, R.; Fazio, E.; Fiannacca, P.; Ortolano, G.; Pezzino, A.; Punturo, R. The Calabria-Peloritani Orogen, a composite terrane in Central Mediterranean; its overall architecture and geodynamic significance for a pre-Alpine scenario around the Tethyan basin. Period. Mineral. 2015, 84, 701-749. [CrossRef]

29. Graessner, T.; Schenk, V.; Brocker, M.; Mezger, K. Geochronological constraints on timing of granitoid magmatism, metamorphism and postmetamorphic cooling in the Hercynian crustal cross-section of Calabria. J. Metam. Geol. 2000, 18, 409-421. [CrossRef]

30. Fiannacca, P.; Williams, I.S.; Cirrincione, R.; Pezzino, A. Poly-orogenic melting of metasedimentary crust from a granite geochemistry and inherited zircon perspective (southern Calabria-Peloritani Orogen, Italy). Front. Earth Sci. 2019, 7, 119. [CrossRef]

31. Rottura, A.; Bargossi, G.M.; Caironi, V.; Del Moro, A.; Maccarrone, E.; Macera, P.; Paglionico, A.; Petrini, R.; Piccarreta, G.; Poli, G. Petrogenesis of contrasting Hercynian granitoids from the Calabrian Arc, Southern Italy. Lithos 1990, 24, 97-119. [CrossRef]

32. Rottura, A.; Del Moro, A.; Pinarelli, L.; Petrini, R.; Peccerillo, A.; Caggianelli, A.; Bargossi, G.M.; Piccarreta, G. Relationships between intermediate and acidic rocks in orogenic granitoid suites: Petrological, geochemical and isotopic ( $\mathrm{Sr}, \mathrm{Nd}, \mathrm{Pb}$ ) data from Capo Vaticano (southern Calabria, Italy). Chem. Geol. 1991, 92, 153-176. [CrossRef]

33. Ayuso, R.; Messina, A.; De Vivo, B.; Russo, S.; Woodruff, L.; Sutter, J.; Belkin, H. Geochemistry and argon thermochronology of the Variscan Sila Batholith, southern Italy: Source rocks and magma evolution. Contrib. Mineral. Petrol. 1994, 117, 87-109. [CrossRef]

34. Fiannacca, P.; Cirrincione, R.; Bonanno, F.; Carciotto, M.M. Source-inherited compositional diversity in granite batholiths: The geochemical message of Late Paleozoic intrusive magmatism in central Calabria (southern Italy). Lithos 2015, 23, 123-140. [CrossRef]

35. Festa, V.; Langone, A.; Caggianelli, A.; Rottura, A. Dike magmatism in the Sila Grande (Calabria, southern Italy): Evidence of Pennsylvanian-Early Permian exhumation. Geosphere 2010, 6, 549-566. [CrossRef]

36. Romano, V.; Cirrincione, R.; Fiannacca, P.; Lustrino, M.; Tranchina, A. Late-Hercynian post-collisional dyke magmatism in central Calabria (Serre Massif, southern Italy). Period Miner. 2011, 80, 489-515. [CrossRef]

37. Barca, D.; Cirrincione, R.; De Vuono, E.; Fiannacca, P.; Ietto, F.; Lo Giudice, A. The Triassic rift system in the northern Calabrian-Peloritani Orogen: Evidence from basaltic dyke magmatism in the San Donato Unit. Period. Mineral. 2010, 79, 61-72. [CrossRef]

38. Cirrincione, R.; Fiannacca, P.; Lustrino, M.; Romano, V.; Tranchina, A. Late Triassic tholeiitic magmatism in Western Sicily: A possible extension of the Central Atlantic Magmatic Province (CAMP) in the Central Mediterranean area? Lithos 2014, 188, 60-71. [CrossRef]

39. Cirrincione, R.; Fiannacca, P.; Lustrino, M.; Romano, V.; Tranchina, A.; Villa, I.M. Enriched asthenosphere melting beneath the nascent North African margin: Trace element and Nd isotope evidence in middle-late Triassic alkali basalts from central Sicily (Italy). Int. J. Earth Sci. 2016, 105, 595-609. [CrossRef]

40. Atzori, P.; Vezzani, L. Lineamenti petrografico-strutturali della catena peloritana. Geol. Romana 1974, 13, $21-27$.

41. Cirrincione, R.; Pezzino, A. Caratteri strutturali dell'evento alpino nella serie mesozoica di Ali e nella Unita metamorfica di Mandanici (Peloritani orientali). Mem. Soc. Geol. Ital. 1991, 47, 263-272.

42. Atzori, P.; Cirrincione, R.; Del Moro, A.; Pezzino, A. Structural, metamorphic and geochronologic features of the Alpine event in south-eastern sector of the Peloritani Mountains (Sicily). Period. Mineral. 1994, 63, 113-125.

43. Cirrincione, R.; Atzori, P.; Pezzino, A. Sub-greenschist facies assemblages of metabasites from south-eastern Peloritani range (NE-Sicily). Mineral. Petrol. 1999, 67, 193-212. [CrossRef]

44. Acquafredda, P.; Lorenzoni, S.; Zanettin Lorenzoni, E. Palaeozoic sequences and evolution of the Calabrian-Peloritan Arc (Southern Italy). Terra Nova 1994, 6, 582-594. [CrossRef]

45. Cirrincione, R.; Fiannacca, P.; Lo Giudice, A.; Pezzino, A. Evidence of early Palaeozoic continental rifting from mafic metavolcanics of Southern Peloritani Mountains (north-eastern Sicily, Italy). Ofioliti 2005, 30, 15-25.

46. Somma, R.; Navas-Parejo, P.; Martín-Algarra, A.; Rodríguez-Cañero, R.; Perrone, V.; Martínez- Pérez, C. Paleozoic stratigraphy of the Longi-Taormina Unit (Peloritanian Mountains, southern Italy). Stratigraphy 2013, 10, 127-152.

47. Ferla, P.; Meli, C. Petrogenesis of tourmaline rocks associated with Fe-carbonate-graphite metapelite, metabasite and strata-bound polymetallic sulphide mineralisation, Peloritani Mountains, Sicily, southern Italy. Lithos 2007, 99, 266-288. [CrossRef] 
48. Fiannacca, P.; Lo Pò, D.; Ortolano, G.; Cirrincione, R.; Pezzino, A. Thermodynamic modeling assisted by multivariate statistical image analysis as a tool for unraveling metamorphic P-T-d evolution: An example from ilmenite-garnet-bearing metapelite of the Peloritani Mountains, southern Italy. Mineral. Petrol. 2012, 106, 151-171. [CrossRef]

49. Atzori, P.; Ferla, P.; Paglionico, A.; Piccarreta, G.; Rottura, A. Remnants of the Variscan Orogen along the Calabrian-Peloritan Arc, southern Italy: A review. J. Geol. Soc. 1984, 141, 137-145. [CrossRef]

50. Ferla, P. A model of continental crust evolution in the geological history of the Peloritani Mountains (Sicily). Mem. Soc. Geol. Ital. 2000, 55, 87-93.

51. Fiannacca, P.; Williams, I.S.; Cirrincione, R.; Pezzino, A. The augen gneisses of the Peloritani Mountains (NE Sicily): Granitoid magma production during rapid evolution of the northern Gondwana margin at the end of the Precambrian. Gondwana Res. 2013, 23, 782-796. [CrossRef]

52. Williams, I.S.; Fiannacca, P.; Cirrincione, R.; Pezzino, A. Peri-Gondwanan origin and early geodynamic history of NE Sicily: A zircon tale from the basement of the Peloritani Mountains. Gondwana Res. 2012, 22, 855-865. [CrossRef]

53. Cirrincione, R.; Fazio, E.; Ortolano, G.; Pezzino, A.; Punturo, R. Fault-related rocks: Deciphering the structural-metamorphic evolution of an accretionary wedge in a collisional belt, NE Sicily. Int. Geol. Rev. 2012, 54, 940-956. [CrossRef]

54. D'Amico, C.; Rottura, A.; Maccarrone, E.; Puglisi, G. Peraluminous granitic suite of Calabria-Peloritani Arc (Southern Italy). Rend. Soc. Ital. Mineral. Petrol. 1982, 38, 35-52.

55. Rottura, A.; Caggianelli, A.; Campana, R.; Del Moro, A. Petrogenesis of Hercynian peraluminous granites from the Calabrian Arc, Italy. Eur. J. Mineral. 1993, 5, 737-754. [CrossRef]

56. Ioppolo, S.; Puglisi, G. Studio petrologico di alcune metamorfiti erciniche dei Monti Peloritani nord orientali (Sicilia). Rend. Soc. Ital. Mineral. Petrol. 1989, 43, 643-656.

57. Rotolo, S.; De Fazio, P. Clinopyroxene bearing garnet amphibolites from the Ferrà Valley (northern Peloritani Mts., Sicily). Boll. Soc. Geol. Ital. 2001, 120, 31-35.

58. Ortolano, G.; Cirrincione, R.; Pezzino, A. PT evolution of Alpine metamorphism in the southern Aspromonte Massif (Calabria-Italy). Schweiz. Mineral. Petrogr. Mitt 2005, 85, 31-56.

59. Ortolano, G.; Visalli, R.; Cirrincione, R.; Rebay, G. PT-path reconstruction via unraveling of peculiar zoning pattern in atoll shaped garnets via image assisted analysis: An example from the Santa Lucia del Mela garnet micaschists (North eastern Sicily-Italy). Period. Mineral. 2014, 83, 257-297. [CrossRef]

60. De Gregorio, S.; Rotolo, S.G.; Villa, I.M. Geochronology of the medium to high grade metamorphic units of the Peloritani Mts., Sicily. Int. J. Earth Sci. 2003, 92, 852-872. [CrossRef]

61. Rubatto, D.; Williams, I.S.; Buick, I.S. Zircon and monazite response to prograde metamorphism in the Reynolds Range, central Australia. Contrib. Mineral. Petrol. 2001, 140, 458-468. [CrossRef]

62. Williams, I.S. Response of detrital zircon and monazite, and their U-Pb isotopic systems, to regional metamorphism and host-rock partial melting, Cooma Complex, southeastern Australia. Aust. J. Earth Sci. 2001, 48, 557-580. [CrossRef]

63. D'Amico, C.; Guerrieri, S.; Maccarrone, E. Le metamorfiti di Milazzo (Messina). Period. Mineral. 1972, 41, $35-151$.

64. Lo Giudice, A.; Atzori, P.; Pezzino, A. Genesi delle masse chiare peloritane ed implicazioni sulle rocce paragneissiche. Mineral. Petrogr. Acta 1985, 29, 93-117.

65. Janoušek, V.; Farrow, C.M.; Erban, V. Interpretation of whole rock geochemical data in igneous geochemistry: Introducing geochemical data toolkit (GCDkit). J. Petrol. 2006, 47, 1255-1259. [CrossRef]

66. Barker, F. Trondhjemites: Definition, environment and hypotheses of origin. In Trondhjemites, Dacites and Related Rocks; Barker, F., Ed.; Elsevier: Amsterdam, The Netherlands, 1979; pp. 1-12. [CrossRef]

67. Fornelli, A.; Piccarreta, G.; Del Moro, A.; Acquafredda, P. Multi-stage melting in the lower crust of the Serre (Southern Italy). J. Petrol. 2002, 43, 2191-2217. [CrossRef]

68. Cruciani, G.; Franceschelli, M.; Elter, F.M.; Puxeddu, M.; Utzeri, D. Petrogenesis of Al-silicate-bearing trondhjemitic migmatites from NE Sardinia, Italy. Lithos 2008, 102, 554-574. [CrossRef]

69. Fancello, D.; Cruciani, G.; Franceschelli, M.; Massonne, H.J. Trondhjemitic leucosomes in paragneisses from NE Sardinia: Geochemistry and P-T conditions of melting and crystallization. Lithos 2018, 304, 501-517. [CrossRef]

70. Sun, S.S.; McDonough, W.F. Chemical and isotopic systematics of oceanic basalts: Implications for mantle composition and processes. In Magmatism in the Ocean Basins; Saunders, A.D., Norry, M.J., Eds.; Special Publications; Geological Society: London, UK, 1989; Volume 42, pp. 313-345. 
71. Boynton, W.V. Geochemistry of rare earth elements: Meteorite studies. In Rare Earth Element Geochemistry; Henderson, P., Ed.; Elsevier: New York, NY, USA, 1984; pp. 63-114. [CrossRef]

72. Brown, C.R.; Yakymchuk, C.; Brown, M.; Fanning, C.M.; Korhonen, F.J.; Piccoli, P.M.; Siddoway, C.S. From source to sink: Petrogenesis of Cretaceous anatectic granites from the Fosdick migmatite-granite complex, West Antarctica. J. Petrol. 2016, 57, 1241-1278. [CrossRef]

73. García-Casco, A.; Torres-Roldán, R.L.; Millán, G.; Monié, P.; Haissen, F. High-grade metamorphism and hydrous melting of metapelites in the Pinos Terrane (W Cuba): Evidence for crustal thickening and extension in the northern Caribbean collisional belt. J. Metamorph. Geol. 2001, 19, 699-715. [CrossRef]

74. Otamendi, J.E.; Patiño Douce, A.E. Partial melting of aluminous metagreywackes in the northern Sierra de Comechingones, Central Argentina. J. Petrol. 2001, 42, 1751-1772. [CrossRef]

75. Gao, L.E.; Zeng, L. Fluxed melting of metapelite and the formation of Miocene high-CaO two-mica granites in the Malashan gneiss dome, southern Tibet. Geochim. Cosmochim. Acta 2014, 130, 136-155. [CrossRef]

76. Jung, S.; Hoernes, S.; Masberg, P.; Hoffer, E. The petrogenesis of some migmatites and granites (central Damara Orogen, Namibia): Evidence for disequilibrium melting, wall-rock contamination and crystal fractionation. J. Petrol. 1999, 40, 1241-1269. [CrossRef]

77. Jung, S.; Hoernes, S.; Mezger, K. Geochronology and petrology of migmatites from the Proterozoic Damara Belt-Importance of episodic fluid-present disequilibrium melting and consequences for granite petrology. Lithos 2000, 51, 153-179. [CrossRef]

78. Ward, R.; Stevens, G.; Kisters, A. Fluid and deformation induced partial melting and melt volumes in low-temperature granulite-facies metasediments, Damara Belt, Namibia. Lithos 2008, 105, 253-271. [CrossRef]

79. Jung, S.; Brandt, S.; Bast, R.; Scherer, E.E.; Berndt, J. Metamorphic petrology of a high-T/low-P granulite terrane (Damara belt, Namibia) - Constraints from pseudosection modelling and high-precision Lu-Hf garnet-whole rock dating. J. Metamorph. Geol. 2019, 37, 41-69. [CrossRef]

80. Sawyer, E.W. Atlas of Migmatites; Special Publication; The Canadian Mineralogist: London, UK, 2008; Volume 9 , p. 371.

81. Vernon, R.H.; Collins, W.J. Structural criteria for identifying granitic cumulates. J. Geol. 2011, 119, $127-142$. [CrossRef]

82. Kriegsman, L.M.; Álvarez-Valero, A.M. Melt-producing versus melt-consuming reactions in pelitic xenoliths and migmatites. Lithos 2010, 116, 310-320. [CrossRef]

83. Acosta-Vigil, A.; Buick, I.; Hermann, J.; Cesare, B.; Rubatto, D.; London, D.; Morgan, G.B. Mechanisms of crustal anatexis: A geochemical study of partially melted metapelitic enclaves and host dacite, SE Spain. J. Petrol. 2010, 51, 785-821. [CrossRef]

84. Bartoli, O.; Tajčmanová, L.; Cesare, B.; Acosta-Vigil, A. Phase equilibria constraints on melting of stromatic migmatites from Ronda (S. Spain): Insights on the formation of peritectic garnet. J. Metamorph. Geol. 2013, 31, 775-789. [CrossRef]

85. Sola, A.M.; Hasalová, P.; Weinberg, R.F.; Suzaño, N.O.; Becchio, R.A.; Hongn, F.D.; Botelho, N. Low-P melting of metapelitic rocks and the role of $\mathrm{H}_{2} \mathrm{O}$ : Insights from phase equilibria modeling. J. Metamorph. Geol. 2017, 35, 1131-1159. [CrossRef]

86. Schwindinger, M.; Weinberg, R.F.; Clos, F. Wet or dry? The difficulty of identifying the presence of water during crustal melting. J. Metamorph. Geol. 2019, 37, 339-358. [CrossRef]

87. Cesare, B.; Acosta-Vigil, A.; Bartoli, O.; Ferrero, S. What can we learn from melt inclusions in migmatites and granulites? Lithos 2015, 239, 186-216. [CrossRef]

88. Bartoli, O.; Acosta-Vigil, A.; Cesare, B. High-temperature metamorphism and crustal melting: Working with melt inclusions. Period. Mineral. 2015, 84, 591-614.

89. Bartoli, O.; Acosta-Vigil, A.; Tajčmanová, L.; Cesare, B.; Bodnar, R.J. Using nanogranitoids and phase equilibria modeling to unravel anatexis in the crustal footwall of the Ronda peridotites (Betic Cordillera, $S$ Spain). Lithos 2016, 256, 282-299. [CrossRef]

90. Bartoli, O.; Acosta-Vigil, A.; Cesare, B.; Remusat, L.; Gonzalez-Cano, A.; Wälle, M.; Tajčmanová, L.; Langone, A. Geochemistry of Eocene-Early Oligocene low-temperature crustal melts from Greater Himalayan Sequence (Nepal): A nanogranitoid perspective. Contrib. Mineral. Pet. 2019, 174, 82. [CrossRef]

91. Acosta-Vigil, A.; London, D.; Morgan, G.B.; Cesare, B.; Buick, I.; Hermann, J.; Bartoli, O. Primary crustal melt compositions: Insights into the controls, mechanisms and timing of generation from kinetics experiments and melt inclusions. Lithos 2017, 286-287, 454-479. [CrossRef] 
92. Villaseca, C.; Barbero, L.; Herreros, V. A reexamination of the typology of peraluminous granite types in intracontinental orogenic belts. Earth Environ. Sci. Trans. R. Soc. Edinb. 1998, 89, 113-119. [CrossRef]

93. Debon, F.; Le Fort, P. A chemical-mineralogical classification of common plutonic rocks and associations. Earth Environ. Sci. Trans. R. Soc. Edinb. 1983, 73, 135-149. [CrossRef]

94. Patiño Douce, A.E. Effects of pressure and $\mathrm{H}_{2} \mathrm{O}$ content on the compositions of primary crustal melts. Specical Pap. Geol. Soc. Am. 1996, 315, 11-21.

95. Cruciani, G.; Fancello, D.; Franceschelli, M.; Scodina, M.; Spano, M.E. Geothermobarometry of Al-silicatebearing migmatites from the Variscan chain of NE Sardinia, Italy: A P-T pseudosection approach. Period. Mineral. 2014, 83, 19-40.

96. Cruciani, G.; Franceschelli, M.; Langone, A.; Puxeddu, M. U-Pb zircon and Ar-Ar amphibole ages from Sardinian migmatites (Italy) and review of migmatite ages from the Variscan belt. Period. Mineral. 2019, 88, 203-221.

(C) 2020 by the authors. Licensee MDPI, Basel, Switzerland. This article is an open access article distributed under the terms and conditions of the Creative Commons Attribution (CC BY) license (http://creativecommons.org/licenses/by/4.0/). 